\title{
Phyto- and Bio-Chemical evaluation of Diospyros kaki L. cultivated in Egypt and its biological activities
}

\author{
S. S. El-Hawary ${ }^{a}$, S. H. Tadros ${ }^{a}$, M. M. AbdelMohsen ${ }^{b *}$ (D), M. S. Mohamed (D), \\ E. El Sheikh ${ }^{b}$ N. M. Nazif (D) and M. S. ElNasr ${ }^{b}$ (D)

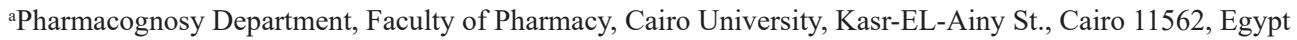 \\ bPhytochemistry Department, National Research Centre, 33 El-Bohouth St., Former El Tahrir St., P.O.12622, \\ Dokki, Giza, Egypt \\ 'Nutrition and Food Sciences Department, National Research Centre, 33 El-Bohouth St., Former El Tahrir St., \\ P.O.12622, Dokki, Giza, Egypt \\ *e-mail: monaamohsen@yahoo.com
}

Received: April 25, 2018 - Accepted: February 18, 2019 - Distributed: May 31, 2020

(With 2 figures)

\begin{abstract}
Diospyros kaki L. or Costata cultivar is the main persimmon variety progressively consumed in the Egyptian market and exportation. The objective of this study was to investigate the bioprotective effects of the alcoholic extract of fruits as well as leaves of D. kaki using in-vivo rat models. Petroleum ether extracts of fruits and leaves were analytically characterized for saponifiable and unsaponifiable compounds by GC/MS. Main flavonoids were chromatographically isolated from $80 \%$ aqueous methanol extract of leaves. Chemical evaluation for fruits and leaves namely, content of moisture, ash, proteins, fatty acids, amino acids, fat and water soluble vitamins, minerals, carotenoids was carried out. Total antioxidant activity was determined by radical scavenging effects using DPPH assay. The effect on biochemical parameters and its biological activity were also performed. Results revealed the identification of the major compounds of saponifiable and unsaponifiable matters of fruits and leaves. Scopoletin, as well as, kaempferol, luteolin, rutin and apigenin 7-O-glucoside were isolated and identified. It showed that this plant can provide a good nutritional value and it is safe regarding the kidney and liver functions, good source that help in enhancing the antioxidant defense against free radicals. No abnormal effects were found in lipids profile on experimental animals and there were good results in the ratio of HDL and LDL cholesterol. Also, this plant can help in optimizing blood sugar, enhancing the level of blood haemoglobin. It is concluded that $D$. kaki displays a good source of nutrients and bioactive compounds that may contribute to its therapeutic benefits against the risk of disease complications.
\end{abstract}

Keywords: Diospyros kaki, GC/MS, flavonoids, antioxidant activity, hyperglycemia.

\section{Avaliação fito e bioquímica de Diospyros kaki L. cultivado no Egito e suas atividades biológicas}

\section{Resumo}

Diospyros kaki L. ou Costata é a principal variedade de caqui progressivamente consumida no mercado e exportação egípcia. O objetivo deste estudo foi investigar os efeitos bioprotetores do extrato alcoólico de frutos e folhas de $D$. kaki utilizando modelos de ratos "in vivo". Extratos de éter de petróleo provenientes de frutos e folhas foram caracterizados analiticamente para compostos saponificáveis e insaponificáveis por GC/MS. Os principais flavonoides foram isolados cromatograficamente, a partir de $80 \%$ de extrato aquoso de folhas de metanol. Foi realizada avaliação química de frutos e folhas, ou seja, de teor de umidade, cinzas, proteínas, ácidos graxos, aminoácidos, vitaminas lipossolúveis e solúveis em água, minerais, carotenoides. Foi caracterizada a atividade antioxidante, utilizando ensaio (DPPH). $\mathrm{O}$ efeito nos parâmetros bioquímicos e sua atividade biológica também foram analisados. Os resultados revelaram a identificação dos principais compostos saponificáveis e insaponificáveis de frutos e folhas. Escopoletina, bem como kaempferol, luteolina, rutina e apigenina 7-O-glicosídeo foram isolados e identificados. Também demonstraram que esta planta pode proporcionar um bom valor nutricional e é segura em relação às funções renais e hepáticas, boa fonte que ajuda a melhorar a defesa antioxidante contra os radicais livres. Não foram encontrados efeitos anormais no perfil lipídico em testes em animais, e houve um efeito satisfatório na relação de colesterol HDL e LDL. Além disso, esta planta pode ajudar na otimização do açúcar no sangue, aumentando o nível de hemoglobina. Conclui-se que o $D$. kaki apresenta uma boa fonte de nutrientes e de compostos bioativos que contribuem para seus benefícios terapêuticos e contra o risco de complicações de doenças.

Palavras-chave: Diospyros kaki, GC/MS, flavonoides, atividade antioxidante, hiperglicemia. 


\section{Introduction}

Medicinal foods are prescribed widely even when their biologically active constituents are unknown, because of their activity, safety, availability and are easy to administer. So, it is worthy to develop some edible compositions with prospects for the expansion of an alternative ways of managing many diseases in the future. The plant kingdom possesses a wide variety of natural substances that have showed significant health properties with few or no documented side effects. These medicinal plants are rich in phytochemical compounds that can provide valuable therapeutic effects for various metabolic diseases such as diabetes, adiposity and cardiovascular complications, offering a source of dietary ingredients that affect human physiological function (Sidik Junior and Ahmad, 2003; Apostolidis et al., 2007), and are increasingly used in the manufacture of food or consumed directly as raw ingredients, being less harmful than synthetic products.

The genus Diospyros belongs to family Ebenaceae and comprises about 500 species distributed in tropical and temperate zone (Hotta et al., 1989). Diospyros kaki, which is native to China, is now known world-wide in tropics and subtropics (Singh and Joshi, 2011). In recent years, it has been favored as tea for healthcare in Southeast Asia for its beneficial effects on homeostasis, hypertension, apoplexy, and atherosclerosis (Lee et al., 2012). As well as, the anti- diabetic, antigenotoxic and neuroprotective activities (Taylor and Hill, 2004; Bei et al., 2007).

Diospyros kaki L. (Oriental persimmon) or Costata cultivar is the main persimmon variety progressively consumed in the Egyptian market and exportation. It grows in clay soil under flood irrigation system. It is known to have many bioactive compounds such as polyphenols, flavonoids, carotenoids, dietary fiber and minerals. Upon continued study of the different constituents in the leaves of Diospyros plants, the present work was designed to find comparative chemical composition of Diospyros kaki fruits and leaves that may correlate with its pharmacological activities. It deals with the chromatographic study of lipid content of the fruits and leaves, isolation of the major coumarin and flavonoidal constituents of the leaves of Diospyros kaki L. growing in Egypt. Also, for the purpose to develop some edible compositions with prospects for the expansion of an alternative ways of managing many diseases in the future, especially in developing countries, a detailed investigation of kaki potentials, chemical determination of the fruits and leaves contents of minerals, tannins, catechin, amino acids, carotenoids and fat and water soluble vitamins has been carried out, in addition, its antioxidant, antilipidemic, and hypoglycemic potentials have been evaluated with regard to the kidney and liver functions.

\section{Materials and Methods}

\subsection{Material for chromatography}

Whatmann paper No.3 MM sheets (Whatmann Ltd., Maidstone, England). Silica gel aluminium sheets G60 (layer thickness $0.2 \mathrm{~mm}$ ) $\mathrm{F}_{254}$ (Fluka Chemie AG, Switzerland). Silica gel 60 for CC mesh size (0.02-0.06), Polyamide 30-60 mesh (Merck, Germany), Sephadex LH-20 (25-100 $\mu \mathrm{m})$ for CC (Sigma-Aldrich Chemie GmbH, Germany).

\subsection{Plant material, extraction and isolation of coumarin and flavonoids}

Fresh fruits and leaves of Diospyros kaki L. cv. Costata were collected during June and August (2015) from Aga Center, Fisha Village, Dakahlia Governorate, Egypt. The collected fruits and leaves of the plant were dried, separately, in an air oven at $40{ }^{\circ} \mathrm{C}$ for three days, then grounded using an electric mill into coarse powder and kept in tightly-closed containers. A voucher specimen was kept at the herbarium of NRC. Each powder was extracted by maceration in petroleum ether $\left(40-60{ }^{\circ} \mathrm{C}\right)$ at room temperature and filtered. For the investigation of lipid content; unsaponifiable and saponifiable matter were obtained for the petroleum ether extracts of both, the fruits and leaves and kept for GC/MS analysis (Ichihara and Fukubayashi, 2010).

For the isolation of coumarin and flavonoids, the defatted marc of powdered leaves was extracted with $80 \%$ aqueous methanol by percolation in room temperature, after complete exhaustion, the extract was filtered. The combined filtrates were dried under pressure. The residue $(250 \mathrm{~g})$ was extracted by successive solvent extraction method using chloroform, ethyl acetate and $n$-butanol (3x 1L) each. The combined portions of each solvent, were evaporated. For separation of the main compounds, the chloroform residue ( $3 \mathrm{~g}$ ) was chromatographed on sephadex LH-20 column using $100 \%$ methanol. The ethyl acetate residue $(8 \mathrm{~g})$ was subjected on the top of silica gel column using gradient elution method. The eluted fractions monitored on silica gel plates for thin layer chromatography and using methylene chloride: methanol, 90:10 v/v, were further purified on sephadex LH-20 column. The $n$-butanol residue was introduced onto the top of polyamide column. Gradient elution of the column was carried out using distilled water and decreasing the polarity by $10 \%$ stepwise addition of methanol. The main fraction $\left(R_{f} 0.28\right.$, paper chromatography $3 \mathrm{MM}, 15 \%$ acetic acid) was rechromatographed on sephadex LH-20 column. Isolated compounds were identified using UV-VIS double beam UVD3500 spectrophotometer, and NMR Joel-300 mHz for ${ }^{1} \mathrm{H}-\mathrm{NMR}$.

\subsection{Phytochemical characterization of lipid content using gas chromatography-mass spectrometry}

The analysis was performed using Gas chromatography-mass spectrometry (GC-MS) methodology using Hewellet Hp 6890 series, gas chromatograph fitted with an injector, and fused silica capillary column $(30 \mathrm{~m}$ x $0.25 \mathrm{~mm}$ i.d. $\mathrm{x} 0.25 \mu \mathrm{m}$ film thickness), composed of a mass spectrophotometer GC-MS Finnigan mat SSQ7000 and electron impact ionization 
detector(EI) with an ion energy of $70 \mathrm{eV}$. The injector temperature was $230^{\circ} \mathrm{C}$. The oven temperature was held at $60{ }^{\circ} \mathrm{C}$ for $1 \mathrm{~min}$, then increased to $230^{\circ} \mathrm{C}$ at a heating rate of $5{ }^{\circ} \mathrm{C} / \mathrm{min}$, then to $300{ }^{\circ} \mathrm{C}$ at $10{ }^{\circ} \mathrm{C} / \mathrm{min}$ and held for $1 \mathrm{~min}$. The carrier gas was helium at a flow rate of $1.5 \mathrm{ml} / \mathrm{min}$. Injection volume was $1 \mu 1$. The identification of compounds was achieved by comparing the retention times with those of authentic compounds and by matching their mass spectra with National Institute of Standards and Technology 05 MS (NIST) library data.

\subsection{Chemical evaluation of fruits and leaves}

Moisture content and ash were determined. Crude protein content and minerals were measured in ashed fruits and leaves by a Varian Model Spectra AA220 Flame Atomic Absorption Spectrophotometer Perkin-Elemer (Model 110 B), (AOAC, 2000).

Catechin content was measured, Total phenolic (as tannins) content was analyzed using Folin Ciocalteu's method and the antioxidant activity was assayed spectrophotometrically according to DPPH free radical scavenging capacity (Haddouchi et al., 2014). Essential and Non-essential amino acids were estimated using an Eppendor Biotronic LC 3000 Amino Acid Analyzer (Eppendorf- Biotronic, Hamburg, Germany), (Yanar et al., 2010). $\beta$-carotene and lycopene were detected using HPLC methods at wave lengths $450 \mathrm{~nm}$ and $472 \mathrm{~nm}$, respectively (Epler et al., 1992). Fat soluble vitamins $A$ and $E$ at $325 \mathrm{~nm}$ and $290 \mathrm{~nm}$, respectively. Water soluble vitamins $\mathrm{B}_{1}$ and $\mathrm{B}_{2}$ at wave lengths $360 \mathrm{~nm}$ and $510 \mathrm{~nm}$, respectively, and vitamin C at $254 \mathrm{~nm}$ (Sami et al., 2014).

\subsection{HPLC analysis conditions for vitamin $A, E, C$, lycopene and $\beta$-carotene}

HPLC separation used a $250 \times 4.0 \mathrm{~mm}$ RP C18, $5 \mu \mathrm{m}$ column (Merck, Darmstadt). The isocratic mobile phase was a mix of acetonitrile and water (75:25). The flow rate applied was $1 \mathrm{ml} / \mathrm{min}$ and analysis were performed at room temperature. Column temperature was maintained at $40^{\circ} \mathrm{C}$ using a column oven. For, vitamin $\mathrm{C}$, the mobile phase applied was a mix of acetonitrile and water (50:50). The dry residues obtained from tetrahydrofuran (THF) extraction of fruits and leaves was saponified with $5.5 \%$ $\mathrm{KOH}$ in ethyl alcohol (w/v) for $15 \mathrm{~min}$ at room temperature. Carotenoids were extracted from the filtrate with the same volume of diethyl ether. The upper phase was evaporated under nitrogen and the dry residue was dissolved with $1 \mathrm{ml}$ of a mixture of $50 \mu \mathrm{THF}+950 \mu \mathrm{l}$ of acetonitrile: water (75:25), filtered through a $0.22 \mu \mathrm{m}$ GHP syringe filter, and transferred into a 2 -ml glass screw-top vial for automatic sampling, using $40 \mu \mathrm{l}$. for injection. For the determination of vitamin $\mathrm{A}$ and $\mathrm{E}, 1 \mathrm{~g}$ of pyrogallic acid, $70 \mathrm{ml}$ ethanol and $30 \mathrm{ml}(50 \%) \mathrm{KOH}$ were added to the samples of fruits and leaves $(5 \mathrm{~g}$, each) for reflux, then extracted with ether, prepared for injection. For vitamin $C$, the samples were homogenized with $10 \mathrm{ml}$ of metaphosphoric acid solution $3 \%(\mathrm{w} / \mathrm{v})$ for one minute, then filtered for HPLC analysis.

\subsection{Biological evaluation of fruits and leaves of Diospyros kaki L.}

\subsubsection{Animals}

Fifteen male Wistar rats (200-220 g) were obtained from the Animal House of the Horticulture Research Institute. The procedure in this study was subjected to the scrutiny of the NRC (FWA 00014747) Animal Ethics Committee and was approved before beginning of the experiment (certificate no. 17-135). Animals were acclimatized to conventional laboratory conditions, and maintained at room temperature $\left(20-25^{\circ} \mathrm{C}\right)$ with free access to water and food.

\subsubsection{Kits}

Kits for the determination of plasma albumin, total protein, alkaline phosphatase, GOT and GPT, creatinine, urea, total cholesterol, HDL cholesterol, LDL-cholesterol, total lipids, triglycerides, malondialdehyde and catalase were obtained from Biodiagnostic Company, BIODIAGNOSTIC, Egypt. Blood glucose was recorded by the Accu-Chek Go and strips that was purchased from Roche. Drabkin's reagent for hemoglobin test was obtained from Vitro Scient.

\subsection{Experimental design}

The rats were randomly divided into three experimental groups. All groups were fed on a balanced diet, containing $15 \%$ Casein ( $80 \%$ protein), $5 \%$ cellulose, $8 \%$ corn oil, $10 \%$ sugar, with adequate vitamin and mineral mixtures as provided by the AIN-93, for one week (Reeves et al., 1993). Then, control group: rats received only the balanced diet as mentioned above.

Fruits group: rats received balanced diet, but, fortified with fruits powder $(10 \%)$ The fresh fruits were collected, dried in an oven, then grounded into coarse powder (as mentioned in plant material) then added to balanced diet in the ratio of 10:90.

Leaves group: rats received balanced diet, but, fortified with leaves powder (10\%) The fresh leaves were collected, dried in an oven, then grounded into coarse powder (as mentioned in plant material) then added to balanced diet in the ratio of 10:90.

All diets were completed to $100 \mathrm{~g}$ using starch. The diets were prepared and stored frozen for the duration of the experiment (4 weeks). At the end of the experiment, rats were fasted overnight, total food intake, final rats body weight gain were recorded. Food efficiency ratio was calculated according to the equation: food efficiency ratio = body weight gain/food intake (Proll et al., 1998). Blood samples were withdrawn from the retro-orbital venous plexus under light ether anesthesia, in heparinized tubes, and the serum was separated by centrifugation at $3000 \mathrm{rpm}$ for $15 \mathrm{~min}$. The plasma was liquated and stored at $-20^{\circ} \mathrm{C}$ until used for biological analysis.

\subsection{Biochemical analysis}

Blood glucose levels (mg/dl) using Accu-check Go strip (Roche) test in a glucometer, haemoglobin ( $\mathrm{mg} / \mathrm{dl}$ ), albumin function $(\mathrm{g} / \mathrm{dl})$ were measured (Louise, 1977; Doumas et al., 1971). Total proteins (g/dl) were measured and Globulin $(\mathrm{g} / \mathrm{dl})$ was calculated by the difference between 
total proteins level and the level of albumin (Gornall et al., 1949). Liver functions such as alkaline phosphatase (ALP), (Belfield and Goldberg, 1971), GOT and GPT activities were determined by the method of Reitman and Frankel (1957). For Kidney function; the levels of creatinine and urea were measured (Bartels et al., 1972; Fawcett and Scott, 1960). The serum lipid Profile including, total cholesterol (Richmond, 1973), total lipids (Zollner and Kirsch 1962), triglycerides (Fossati and Prencipe, 1982), HDL-and LDL-cholesterol were determined. The antioxidant Enzymes; Catalase activity (Sinha, 1972), and malondialdehyde (MDA) (Ohkawa et al., 1979) were measured.

\subsection{Statistical analysis}

Statistical analysis was carried out by one-way analysis of variance (ANOVA) followed by Tukey test. Expression of data was done as mean \pm SD. $P<0.05$ was considered statistically significant.

\section{Results}

3.1. Gas Chromatography-Mass Spectrometry of unsaponifiable Matter of Fruits and Leavesof Diospyros kaki L.

GC-MS analysis of the unsaponifiable matter of fruits revealed the identification of 13 compounds, representing $85.61 \%$ of the total. Oxygenated compounds constituted the major percent $(84.38 \%)$, in which aromatic compounds were the major $(57.52 \%)$. Phthalic acid bis (2-ethylhexyl) phthalate was predominant $(42.9 \%)$. GC-MS analysis of the unsaponifiable matter of leaves revealed the identification of 10 compounds, representing $87.16 \%$ of the total. The oxygenated compounds constituted the major percent $(70.67 \%)$, in which terpene compounds were the major (56.81\%). $\alpha$-amyrin $(42.39 \%)$ constituted the major terpene (See Figure 1).

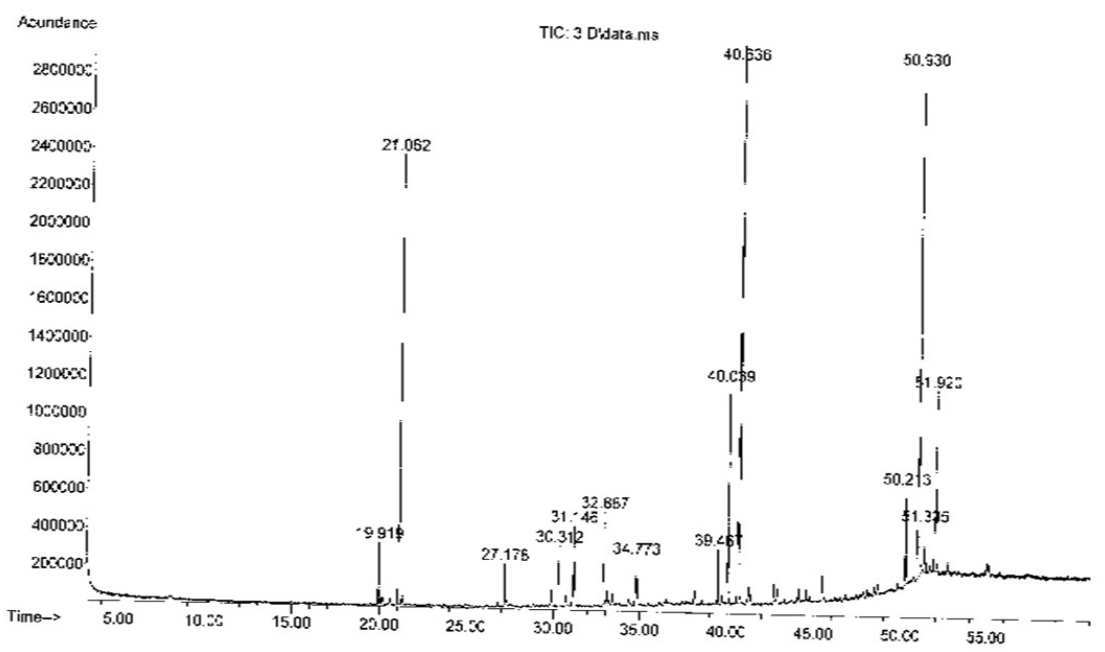

(a)

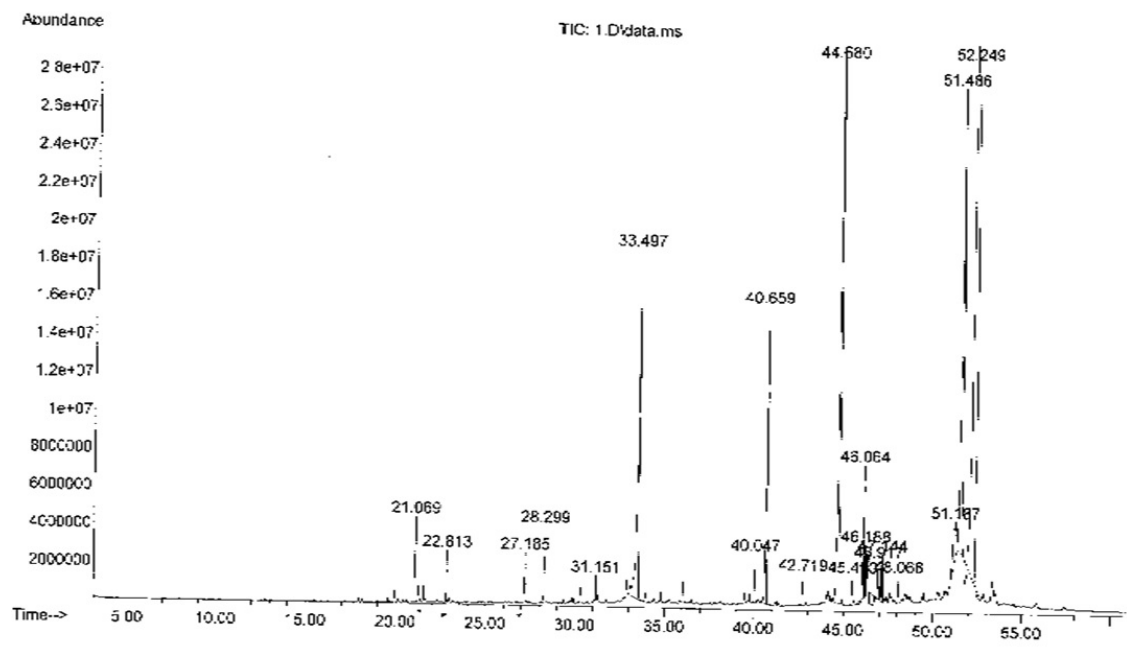

(b)

Figure 1. GC-MS chromatogram of unsaponifiable matter of fruits (a) and leaves (b). 


\subsection{Gas Chromatography-Mass Spectrometry of} saponifiable Matter (Fatty Acids) of Fruits and Leaves of Diospyros kaki L.

GC/MS analysis of the fatty acids methyl esters of fruits revealed the presence of 13 fatty acids, representing $84.79 \%$ of the total, the major of which was ethyl stearate (saturated, 26.87\%) and methyl palmitoleate (unsaturated, 9.68\%). GC/MS analysis of the fatty acids methyl esters of leaves revealed the presence of 10 fatty acids, representing $91.07 \%$ of the total. The major saturated fatty acid methyl ester was methyl palmitate $(40.74 \%)$, while the major unsaturated fatty acid methyl ester was methyl 9-octadecenoate (17.61\%), (See Figure 2).

\subsection{Identification of isolated compounds}

Four flavonoids and one coumarin were isolated from the aqueous methanol extract ( $80 \%$ ) of leaves of Diospyros kaki L.; Kaempferol and scopoletin were isolated from chloroform fraction, luteolin and rutin from ethyl acetate fraction, and apigenin 7-O-glucoside from $n$-butanol fraction. All compounds were identified on the basis of their absorption bands in the ultraviolet/visible region, and ${ }^{1} \mathrm{H}-\mathrm{NMR}$ spectral data which were confirmed by comparison with that reported in the literature (Mabry et al., 1970).

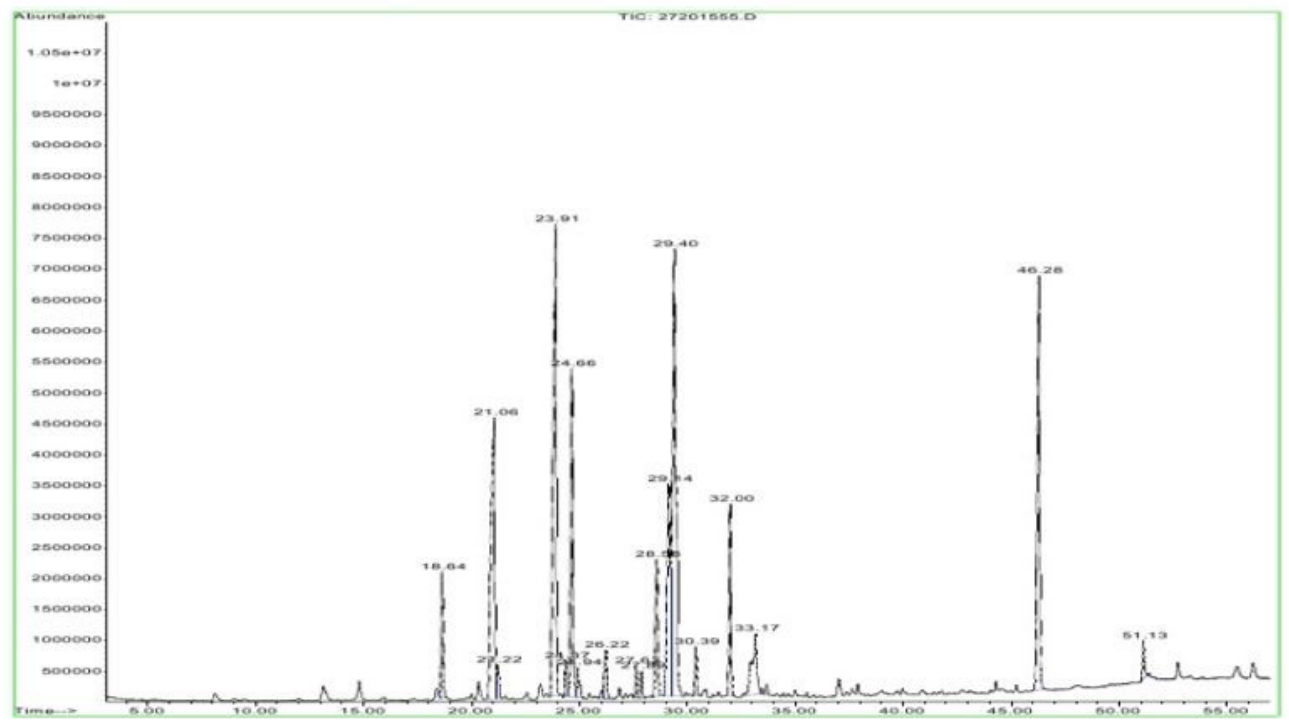

(A)

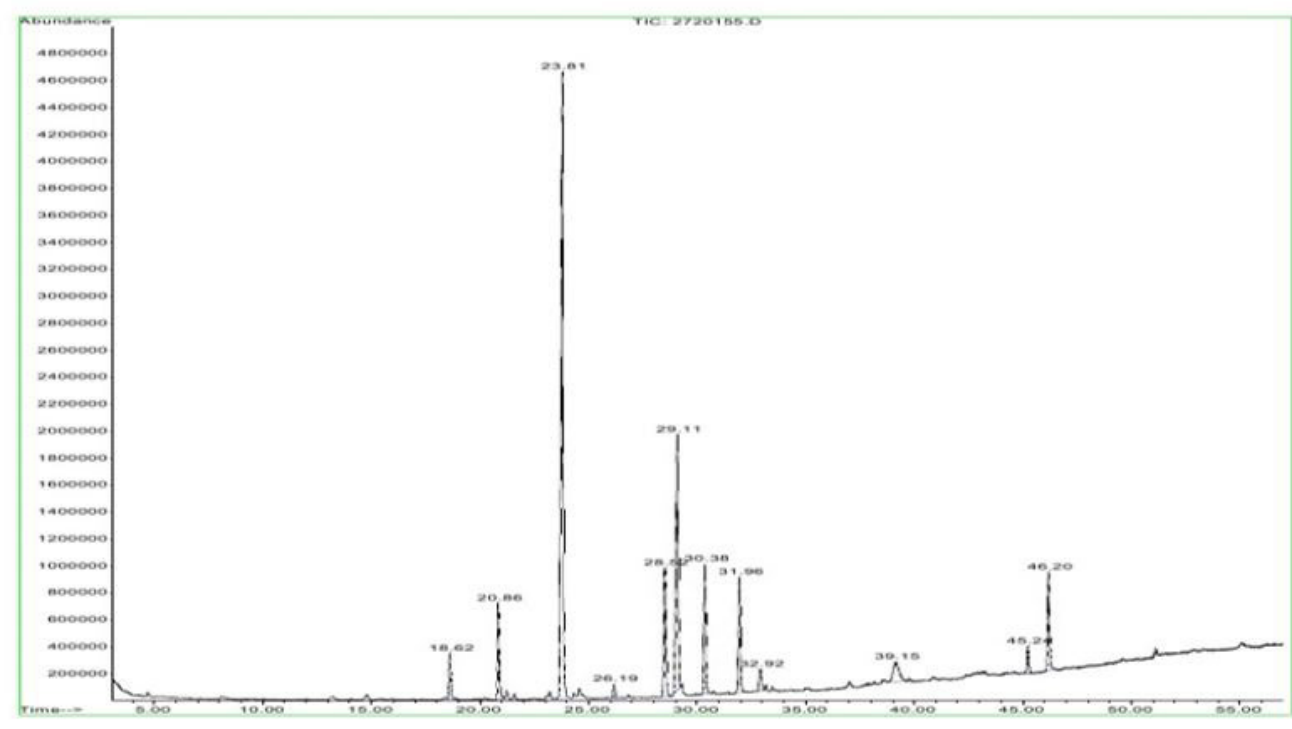

(B)

Figure 2. GC-MS chromatogram of saponifiable matter of fruits (A) and leaves (B). 


\subsection{Moisture, ash, proteins and minerals}

The results (as shown in Table 1), showed that the moisture content was higher in fruits, while ash was less than the leaves, and almost equal percentage in protein content. The major macro elements were potassium and calcium in the fruits, while phosphorous, magnesium and sodium were the major in leaves, which also contained higher amounts of micro elements $(\mathrm{mg} / \mathrm{kg})$ dry weight.

\subsection{Chemical Evaluation of Fruits and Leaves}

Evaluation of amino acid content, showed that the fruits contained higher level of non-essential amino acids $(884.8 \mathrm{mg} / 100 \mathrm{~g})$, while leaves content of essential amino acids was higher $(912.1 \mathrm{mg} / 100 \mathrm{~kg})$. Carotenoids analysis, showed that the fruits content of $\beta$-carotene and lycopene was higher than the leaves. As for vitamins, the fruits were found to contain higher content of vitamin $\mathrm{B}, \mathrm{C}$ and $\mathrm{E}$, however, the leaves contained higher content of $\mathrm{A}$ and $\mathrm{B}_{2}$ (as shown in Table 2).

\subsection{Biochemical analysis}

Results showed that, no significant differences $(p<0.05)$ were found in the levels of total food intake or food efficiency ratios between all experimental groups. However, at the end of the experimental period, the group fed with fruits diet, demonstrated a significant decrease in blood glucose level, also a significant increase in the blood hemoglobin level (as shown in Table 3). The results obtained for liver and kidney functions, showed no significant difference in all the evaluated parameters, all the values agreed with the control group fed on the balanced diet (as shown in Table 4). The healthy effect of Diospyros kaki L. fruits and leaves on the plasma lipid profile showed a significant reduction $(p<0.05)$ in the plasma total cholesterol and triglycerides values, but non-significant decrease in total lipids. Also, showed non-significant increase in HDL/LDL ratio (as shown

Table 1. Moisture, ash, protein (\%), and minerals content of fruits and leaves of Diospyros kaki L.

\begin{tabular}{lcr}
\hline \multicolumn{1}{c}{ Parameter } & Fruits & \multicolumn{1}{c}{ Leaves } \\
\hline Moisture $(\% \mathrm{~W} / \mathrm{W})$ & $92.6 \pm 1.1$ & $89.6 \pm 0.6$ \\
Ash $(\% \mathrm{~W} / \mathrm{W})$ & $0.8 \pm 0.2$ & $1.6 \pm 0.1$ \\
Protein $(\% \mathrm{~W} / \mathrm{W})$ & $0.7 \pm 0.1$ & $0.9 \pm 0.2$ \\
Macro Elements $(\mathrm{mg} / \mathrm{kg})$ & Dry Weight & \\
Potassium & $5791.1 \pm 10.6$ & $2299.7 \pm 8.1$ \\
Phosphorus & $848.7 \pm 0.1$ & $1080.7 \pm 1.8$ \\
Calcium & $1368.8 \pm 3.0$ & $279.7 \pm 0.1$ \\
Magnesium & $2141 \pm 5.1$ & $2487.1 \pm 1.1$ \\
Sodium & $1860.2 \pm 1.2$ & $2470.1 \pm 4.5$ \\
Micro Elements (mg/kg) Dry Weight & \\
Iron & $26.7 \pm 1.4$ & $753.7 \pm 1.8$ \\
Zinc & $45.6 \pm 0.5$ & $50.8 \pm 0.2$ \\
Copper & $2.5 \pm 0.1$ & $13.6 \pm 0.6$ \\
\hline
\end{tabular}

Values are mean $\pm \mathrm{SD}$. in Table 4). For the antioxidant enzymes; catalase and MDA, the results showed no significant decrease in their activities when comparing the fruits and leaves groups to the control group (as shown in Table 4).

Table 2. Chemical evaluation of fruits and leaves of Diospyros kaki L.

\begin{tabular}{lrr}
\hline \multicolumn{1}{c}{ Parameter } & Fruits & Leaves \\
\hline Catechin $(\mathrm{mg} / \mathrm{kg})$ & 8270.9 & 5890.2 \\
Tannins $(\mathrm{mg} / \mathrm{kg})$ & 10610.2 & 11770.7
\end{tabular}

Non-essential amino acids

$(\mathrm{mg} / \mathrm{kg})$

$\begin{array}{lcc}\text { Aspartic acid } & 1260.6 & 1240.1 \\ \text { Serine } & 480.2 & 230.2 \\ \text { Glutamic acid } & 790.3 & 460.9 \\ \text { Glycine } & 400 & 370.8 \\ \text { Alanine } & 960.6 & 1200.6 \\ \text { Cystine } & 116.5 & - \\ \text { Tyrosine } & 1990.4 & 1140.1 \\ \text { Proline } & 1780.2 & 1200.5\end{array}$

Essential amino acids

(mg/kg)

$\begin{array}{lll}\text { Threonine } & 540.5 & 1020.6\end{array}$

$\begin{array}{lll}\text { Methionine } & 750.7 & 400.4\end{array}$

$\begin{array}{lll}\text { Isoleucine } & 390.2 & 1050.1\end{array}$

$\begin{array}{lll}\text { Leucine } & 76.9 & 47.4\end{array}$

$\begin{array}{lll}\text { Phenylalanine } & 710.3 & 1600.4\end{array}$

$\begin{array}{lll}\text { Histidine } & 1180.3 & 1030\end{array}$

$\begin{array}{lll}\text { Lysine } & 560.6 & 1230.4\end{array}$

$\begin{array}{lll}\text { Valine } & 340.6 & 710.1\end{array}$

$\begin{array}{lll}\text { Arginine } & 1050.3 & 1580.7\end{array}$

Carotenoids (mg/kg)

$\begin{array}{lll}\beta \text {-carotene } & 210.4 & 130.2\end{array}$

$\begin{array}{lll}\text { Lycopene } & 1470.3 & 140.7\end{array}$

Fat soluble vitamins

(mg/kg)

$\begin{array}{lrr}\text { Vitamin A } & 120.8 & 800.7\end{array}$

$\begin{array}{lll}\text { Vitamin E } & 2780.2 & 3250.9\end{array}$

Water soluble vitamins

$(\mathrm{mg} / \mathrm{kg})$

$\begin{array}{lll}\text { Vitamin } \mathrm{B}_{1} & 480.9 & 430.1\end{array}$

$\begin{array}{lll}\text { Vitamin } \mathrm{B}_{2} & 430.2 & 470.7\end{array}$

\begin{tabular}{lll} 
Vitamin $\mathrm{C}^{2}$ & 620.9 & 590.3 \\
\hline
\end{tabular}

Table 3. Blood glucose and hemoglobin levels of experimental groups.

\begin{tabular}{lcc}
\hline \multicolumn{1}{c}{ Group* } & $\begin{array}{c}\text { Glucose** }^{* *} \\
(\mathbf{m g} / \mathbf{d l})\end{array}$ & $\begin{array}{c}\text { Hemoglobin** } \\
(\mathbf{m g} / \mathbf{d l})\end{array}$ \\
\hline Control diet & $88 \pm 12^{\mathrm{a}}$ & $15.03 \pm 0.77^{\mathrm{ab}}$ \\
Fruits diet & $63.67 \pm 4.04^{\mathrm{b}}$ & $16.76 \pm 2.62^{\mathrm{a}}$ \\
Leaves diet & $75.67 \pm 15.57^{\mathrm{ab}}$ & $13.36 \pm 0.54^{\mathrm{b}}$ \\
\hline
\end{tabular}

**Values are means \pm SD. Same letters in each column means non-significant difference; Different letter means significance difference $(\mathrm{p}<0.05)$. 
Table 4. Liver and kidney function of experimental groups.

\begin{tabular}{|c|c|c|c|}
\hline \multirow{2}{*}{ Parameter } & \multicolumn{3}{|c|}{ Groups } \\
\hline & Control & Fruits & Leaves \\
\hline \multicolumn{4}{|l|}{ Liver function } \\
\hline Albumin (g/dl) & $3.75 \pm 0.21^{\mathrm{a}}$ & $4.09 \pm 0.20^{\mathrm{a}}$ & $3.86 \pm 0.22^{\mathrm{a}}$ \\
\hline Total protein $(\mathrm{g} / \mathrm{dl})$ & $8.49 \pm 2.10^{\mathrm{a}}$ & $8.60 \pm 2.32^{a}$ & $9.85 \pm 0.46^{\mathrm{a}}$ \\
\hline $\operatorname{ALP}(\mathrm{mg} / \mathrm{dl})$ & $176.6 \pm 40.90^{\mathrm{a}}$ & $168.1 \pm 22.58^{a}$ & $158.6 \pm 17.59^{\mathrm{a}}$ \\
\hline GOT (unit / ml) & $66.0 \pm 0.38^{\mathrm{a}}$ & $63.0 \pm 0.23^{\mathrm{a}}$ & $65.0 \pm 0.02^{\mathrm{a}}$ \\
\hline GPT (unit / ml) & $35.0 \pm 0.06^{\mathrm{a}}$ & $32.0 \pm 0.04^{\mathrm{a}}$ & $34.2 \pm 0.02^{\mathrm{a}}$ \\
\hline \multicolumn{4}{|l|}{ Kidney function } \\
\hline Creatinine (mg/dl) & $3.6 \pm 0.71^{\mathrm{a}}$ & $3.3 \pm 0.78^{a}$ & $3.5 \pm 1.19^{\mathrm{a}}$ \\
\hline Urea $(\mathrm{mg} / \mathrm{dl})$ & $86.21 \pm 1.57^{\text {a }}$ & $76.13 \pm 7.35^{\mathrm{a}}$ & $72.77 \pm 4.03^{\mathrm{a}}$ \\
\hline \multicolumn{4}{|l|}{ Lipid profile } \\
\hline Total cholesterol (mg/dl) & $102.68 \pm 2.38^{b}$ & $96.86 \pm 6.62^{b}$ & $81.05 \pm 8.41^{\mathrm{a}}$ \\
\hline \multicolumn{4}{|l|}{ Total lipids (mg/dl) } \\
\hline Triglycerides (mg/dl) & $502.97 \pm 134.89^{\text {a }}$ & $438.71 \pm 175^{\text {a }}$ & $441.93 \pm 17.7^{\mathrm{a}}$ \\
\hline $\mathrm{HDL}(\mathrm{mg} / \mathrm{dl})$ & $92.77 \pm 2.94^{\mathrm{ab}}$ & $80.52 \pm 8.37^{\text {a }}$ & $68.52 \pm 11.31^{b}$ \\
\hline LDL (mg/dl) & $40.2 \pm 5.10^{a}$ & $73.6 \pm 6.3^{\mathrm{a}}$ & $60.4 \pm 2.2^{\mathrm{a}}$ \\
\hline HDL/LDL ratio & $160.9 \pm 14.2^{\mathrm{a}}$ & $143.3 \pm 23.2^{\mathrm{a}}$ & $125.3 \pm 21.3^{\mathrm{a}}$ \\
\hline Antioxidant elements & $0.24 \pm 0.03^{\mathrm{a}}$ & $0.52 \pm 0.04^{\mathrm{a}}$ & $0.48 \pm 0.01^{\mathrm{a}}$ \\
\hline Catalase (U/L) & $453.8 \pm 20.2^{\mathrm{a}}$ & $415.4 \pm 29.2^{\mathrm{a}}$ & $428.8 \pm 30.3^{a}$ \\
\hline $\operatorname{MDA}(\mathrm{U} / \mathrm{L})$ & $3.7 \pm 0.6^{\mathrm{a}}$ & $3.5 \pm 0.8^{\mathrm{a}}$ & $3.2 \pm 0.3^{\mathrm{a}}$ \\
\hline
\end{tabular}

Values are means \pm SD. Same letters in each row means non-significant difference; different letters mean significant difference $(\mathrm{p}<0.05)$.

\subsection{DPPH results}

The DPPH assay has been used because it is rapid, simple and due to the stability of the DPPH radical (Sun et al., 2011). The free radical scavenging activity of the aqueous methanolic extract of the fruits and leaves were determined through the DPPH method, Trolox (Sigma-Aldrich), an antioxidant, was used as a synthetic reference. The results showed that the leaves extract had higher antioxidant activity $(93.3 \%)$ than that of fruits $(83.2 \%)$ both being comparable to that of Trolox $(98.5 \%)$. Since there are a large number of different types of antioxidant compounds, it is not clear which exactly are responsible for the observed antioxidant activity. It has been shown that high phenolic content increases this activity. The antioxidant activity of Diospyros kaki extracts are due to the presence of these phytochemicals, including, tannins which are the main phenolic compound of persimmon kaki, carotenoids, and vitamin C (Veberic et al., 2010). In the current investigation, the leaf extract was more potent antioxidant, suggesting that the activity is mainly due to more polar constituents, revealing the presence of flavonoids and was also justified by the higher content of tannins compared to that of fruits, which on the other hand, contained higher amounts of catechin, (as shown in Table 2). Thereby providing an ample advocacy of the use of the plant as an alternative source of natural antioxidants (Noreen et al., 2017).

\section{Discussion}

Recent studies have found the association between the lower status of dietary antioxidants and decline in the cognitive function, as increasing intake of natural antioxidants may help to maintain a tolerable antioxidant status. Plant phenolic compounds in the human diet are numerous. Plants consumed by humans contain thousands of dietary polyphenols, the effect of which are of great importance because of their antioxidative properties. They scavenge free radicals, thus breaking the free radical chain reaction of lipid peroxidation. Polyphenols, also quench reactive oxygen and nitrogen species generated in biological systems (Farkas et al., 2004; Pal et al., 2012). Components of these plants with natural occurring antioxidant activity can be used to control the balance between free radicals and antioxidant stress in diabetic patients (Manaharan et al.,2011; Gulati et al., 2012). Persimmon, like other fruits contains a number of functional compounds which are useful in promoting human health. The present work is aimed at appraising the chemical profile of fruits and leaves of persimmon (Diospyros kaki) with reference to its prospective bioactive components to encourage impending applications in disease prevention.

In the present study, the GC-MS analysis of the petroleum ether extract of fruits and leaves, revealed that aromatic compounds were the major oxygenated compounds of the unsaponifiable matter (57.52\%), and the major fatty acid methyl ester was that of palmitic acid (40.74\%), which exhibit antioxidant activity (Richard et al., 2008).

Previous studies suggest that the flavonoids present in persimmon leaves could contribute to its health benefits (Bei et al., 2009). Four flavonoids were isolated from the aqueous methanol extract of Diospyros kaki L. leaves in this study, namely, Kaempferol, luteolin, apigenin 7-O-glucoside, representing flavonols and flavones 
containing a catechol group in ring B, these compounds are found to be highly active, with flavonols more potent than the corresponding flavones because of the presence of the 3-hydroxyl group. Rutin, was also isolated, it is a lipidsoluble analogue of flavonoids, with C-3 glycoside group in ring C. Notice that, this galloylated flavonol glycoside mixture had a strong antioxidant activity approximately two fold stronger than that of the non galloylated flavonol glycosides (Kawakami et al., 2011). The total flavonoids containing aqueous methanol extract of kaki leaves possess a good water-soluble efficacy, and its flavonoid aglycones, reportedly possess strong antioxidant activities by acting as oxygen radical scavengers and metal chelators (Birt et al., 2001). These polyphenols prevent the diabetes resulting from oxidative stress, suggesting the relation to its protective effect and antihyperglycemic activity (Sancheti et al., 2011; Choi et al., 2016).

The persimmon contains various bioactive substances that are valuable for the proper physiology of human health. Our results revealed that the fruits contain higher amounts of potassium (5791.1 $\mathrm{mg} / \mathrm{kg}$ ), and calcium $(1368.8 \mathrm{mg} / \mathrm{kg})$, while leaves contain higher amounts of phosphorus (1080.7 mg/kg), magnesium (2487.1 mg/kg) and iron $(753.7 \mathrm{mg} / \mathrm{kg})$, beside other minerals, including, zinc and copper (as shown in Table 1).

Tannins, which are an important group of phenolics, were found in high concentrations in fruits $(1061.2 \mathrm{mg} / 100 \mathrm{~g})$ and leaves $(1177.7 \mathrm{mg} / 100 \mathrm{~g})$ as shown in Table 2 . These group of compounds present in persimmon are 20 times more potent than antioxidant vitamin E (Ueda et al., 2013). Dietary intake of persimmon tannin was found to prevent hypercholesterolemia in some animal models and humans (Gato et al., 2013). The fruits showed a higher concentration of catechin $(827.9 \mathrm{mg} / 100 \mathrm{~g})$ and are also rich in lycopene $(147.3 \mathrm{mg} / 100 \mathrm{~g})$ beside $\beta$-carotene $(21.4 \mathrm{mg} / 100 \mathrm{~g})$, notice that these are excellent lipid-soluble antioxidants, having the ability to scavenge free radicals in a lipid-soluble environment and thus preventing the oxidation of lipids. These antioxidant activities could contribute, at least in part, to the traditionally claimed therapeutic benefits of persimmon leaves. Some of these carotenoids present in persimmon are precursors of vitamin A, having immunoregulatory and antiaging effects. The findings of this study showed that fruits and leaves had a significant reduction in plasma total cholesterol and triglycerides values (as shown in Table 4), which agreed to the beneficial effects of the kaki leaves as an anti-atherosclerosis, where the lowering effects of this leaves in the triglyceride, total cholesterol, LDL-Cholesterol levels and the increasing effect on the HDL level in blood of the experimental rats were studied and confirmed (Matsumoto et al.,2006). Fruits and leaves showed high levels of vitamin E $(278.2 \mathrm{mg} / 100 \mathrm{~g}$ and $325.19 \mathrm{mg} / 100 \mathrm{~g}$ respectively), vitamin C (62.9 mg/100g and $59.3 \mathrm{mg} / 100 \mathrm{~g}$ respectively). Thus, Diospyros kaki is an excellent source of ascorbic acid, vitamin E, tannins and carotenoids, having healthy aspects owing to their antioxidant and other health protecting activities (Karaman et al., 2014).
Medicinal plants are widely used by the population of developing countries as alternative therapy. The development of novel prophylactic approaches is required for the prevention of diabetic disease. Egypt, presently, is one country with leading number of diabetics. Our study gives a considerable focus on the edible nutritious dietary supplement from Diospyros kaki to treat diabetes and its associated toxic manifestations. It is interesting to notify that persimmon leaves tea is infused with hot water and drunk as green tea in Japan, as it has been regarded as a famous nutrient and anti-aging tea rich in vitamin $C$, thus its regular consumption is considered to be extremely useful in arresting degenerative and senescence process, promoting longevity, enlivening the body and enhance immunity (Tsurunaga et al., 2011), Naoxinqing tablet made from the extract of persimmon leaves have been recorded in Chinese Pharmacopeia 2010, and is patented and approved drug of Traditional Chinese Medicine (TCM) used for the treatment of cerebral arteriosclerosis (ChPC, 2012).

\section{Conclusion}

In conclusion, the present study showed that Diospyros $k a k i$ is a rich source of dietary fibers, minerals, vitamins and considerable amounts of phenolic compounds, which appear to be responsible for its significant antioxidant potential and may contribute to the therapeutic activity observed. Our results encourage wide cultivation and local consumption. Further investigation to determine the potential use of kaki leaves in the functional food industry could be considered.

\section{Acknowledgements}

The authors gratefully acknowledge the help of Dr. Abd El-Halim Abd El-Mogali Mohamed, Professor, Flora and Phytotaxonomy Research Department, Agricultural Museum, Dokki, Giza, for sample authentication.

\section{References}

APOSTOLIDIS, E., KWON, Y.I. and SHETTY, K., 2007. Inhibitory potential of herb, fruit, and fungal-enriched cheese against key enzymes linked to type 2 diabetes and hypertension. Innovative Food Science \& Emerging Technologies, vol. 8, no. 1, pp. 46-54. http://dx.doi.org/10.1016/j.ifset.2006.06.001.

ASSOCIATION OF OFFICIAL ANALYTICAL CHEMISTS AOAC, 2000. Official Methods of Analysis of AOAC International: AOAC official method 992.23. Arington: AOAC, vol. 2.

BARTELS, H., BÖHMER, M. and HEIERLI, C., 1972. Serum creatinine determination without protein precipitation. Clinica Chimica Acta, vol. 37, pp. 193-197. PMid:5022083.

BEI, W., PENG, W., ZANG, L., XIE, Z., HU, D. and XU, A., 2007. Neuroprotective effects of a standardized extract of Diospyros kaki leaves on MCAO transient focal cerebral ischemic rats and cultured neurons injured by glutamate or hypoxia. Planta Medica, vol. 73, no. 7, pp. 636-643. http://dx.doi.org/10.1055/s-2007-981532. PMid: 17583826 
BEI, W., ZANG, L., GUO, J., PENG, W., XU, A., GOOD, D.A., HU, Y., WU, W., HU, D., ZHU, X., WEI, M. and LI, C., 2009. Neuroprotective effects of a standardized flavonoid extract from Diospyros kaki leaves. Journal of Ethnopharmacology, vol. 126, no. 1, pp. 134-142. http://dx.doi.org/10.1016/j.jep.2009.07.034. PMid:19665536.

BELFIELD, A. and GOLDBERG, D.M., 1971. Revised assay for serum phenyl phosphatase activity using 4-amino-antipyrine. Enzyme, vol. 12, no. 5, pp. 56. http://dx.doi.org/10.1159/000459586. PMid:5169852.

BIRT, D.F., HENDRICH, S. and WANG, W.Q., 2001. Dietory agents in cancer prevention: flavonoids and isoflavonoids. Pharmacology \& Therapeutics, vol. 90, no. 2-3, pp. 157-177. http:// dx.doi.org/10.1016/S0163-7258(01)00137-1. PMid:11578656.

CHINESE PHARMACOPOEIA COMMISSION - ChPC, 2012. The first supplement of Chinese Pharmacopoeia. Beijing: China Medical Science Press.

CHOI, M., JEONG, M.J., PARK, Y.B., KIM, S.R. and JUNG, U.J., 2016. The leaf of Diospyros kaki Thumb ameliorates renal oxidative damage in mice with type 2 diabetes. Preventive Nutrition and Food Science, vol. 21, no. 4, pp. 378-383. http:// dx.doi.org/10.3746/pnf.2016.21.4.378. PMid:28078262.

DOUMAS, B.T., WATSON, W.A. and BIGGS, H.G., 1971. Albumin standards and the measurement of serum albumin with bromocresol green. Clinica Chimica Acta, vol. 31, no. 1, pp. 87-96. http://dx.doi.org/10.1016/0009-8981(71)90365-2. PMid:5544065.

EPLER, K.S., SANDER, L.C., ZIEGLER, R.G., WISE, S.A. and CRAFT, N.E., 1992. Evaluation of reversed-phase liquid chromatographic columns for recovery and selectivity of selected carotenoids. Journal of Chromatography, vol. 595, no. 1-2, pp. 89-101. http://dx.doi.org/10.1016/0021-9673(92)85149-N. PMid:1577914.

FARKAS, O., JAKUS, J. and HÉBERGER, J., 2004. Quantitative structure -antioxidant activity relationships of flavonoid compounds. Molecules, vol. 9, no. 12, pp. 1079-1088. http:// dx.doi.org/10.3390/91201079. PMid:18007505.

FOSSATI, P. and PRENCIPE, L., 1982. Serum Triglyceride determined calorimetrically with an enzyme that produces hydrogen peroxide. Clinical Chemistry, vol. 28, no. 10, pp. 2077-2080. PMid:6812986.

FAWCETT, J.K. and SCOTT, J.E., 1960. A rapid and precise method for the determination of urea. Journal of Clinical Pathology, vol. 13, no. 2, pp. 156-159. http://dx.doi.org/10.1136/ jcp.13.2.156. PMid:13821779.

GATO, N., KADOWAKI, A., HASHIMOTO, S., YOKOYAMA, I. and MATSUMOTO, K., 2013. Persimmon fruit tanninrich fiber reduces cholesterol levels in humans. Annals of Nutrition \& Metabolism, vol. 62, no. 1, pp. 1-6. http://dx.doi. org/10.1159/000343787. PMid:23171573.

GORNALL, C., BARDAWAILL, J. and DAVID, M., 1949. Determination of serum proteins by means of the biuret reaction. The Journal of Biological Chemistry, vol. 177, no. 2, pp. 751766. PMid: 18110453.

GULATI, V., HARDING, I.H. and PALOMBO, E.A., 2012. Enzyme inhibitory and antioxidant activities of traditional medicinal plants: potential application in the management of hyperglycemia. BMC Complementary and Alternative Medicine, vol. 12, no. 1, pp. 77. http://dx.doi.org/10.1186/1472-6882-12-77. PMid:22713130.
HADDOUCHI, F., CHAOUCHE, T.M., KSOURI, R., MEDINI, F., SEKKAL, F.Z. and BENMANSOUR, A., 2014. Antioxidant activity profiling by spectrophotometric methods of aqueous methanolic extracts of Helichrysum stoechas subsp. Rupestre and Phagnalon saxatile subsp. saxatile. Chinese Journal of Natural Medicines, vol. 12, no. 6, pp. 415-422. http://dx.doi.org/10.1016/ S1875-5364(14)60065-0. PMid:24969521.

HOTTA, M., OGATA, K., NITTA, A., HOSAKAWA, K., YANAGI, M. and YAMAZAKI, K. 1989. Useful plants of the world. Japan: Heibonsha, pp. 386-389.

ICHIHARA, K. and FUKUBAYASHI, Y., 2010. Preparation of fatty acid methyl esters for gas-liquid chromatography. Journal of Lipid Research, vol. 51, no. 3, pp. 635-640. http://dx.doi. org/10.1194/jlr.D001065. PMid:19759389.

LEE, J.H., LEE, Y.B., SEO, W.D., KANG, S.T., LIM, J.W. and CHO, K.M, 2012. Comparative studies of antioxidant activities and nutritional constituents of persimmon juice (Diospyros kaki L. cv. Gapjubaekmok). Preventive Nutrition and Food Science, vol. 17, no. 2, pp. 141-151. http://dx.doi.org/10.3746/pnf.2012.17.2.141. PMid:24471076.

KARAMAN, S., TOKER, O.S., YÜKSEL, F., ÇAM, M., KAYACIER, A. and DOGAN, M., 2014. Physicochemical, bioactive, and sensory properties of persimmon-based ice cream: technique for order preference by similarity to ideal solution to determine optimum concentration. Journal of Dairy Science, vol. 97, no. 1, pp. 97-110. http://dx.doi.org/10.3168/jds.2013-7111. PMid:24268400.

KAWAKAMI, K., SHIBUKURA, Y., KANNO, T., FURUKI, T., AKETA, S. and HIRAYAMA, M., 2011. Identification of 2"-galloylated flavonol 3-O-glycosides accumulating in developing leaves of persimmon. Phytochemical Analysis, vol. 22, no. 5, pp. 403-410. http://dx.doi.org/10.1002/pca.1295. PMid:21413094.

LOUISE, T.M., 1977. Clinical Hematology: theories and procedures. 3rd ed. Boston: LWW, pp. 317-318.

MABRY, T.J., MARKHAM, K.R. and THOMAS, M.B. 1970. The systematic identification of flavonoids. New York: Springer. http://dx.doi.org/10.1007/978-3-642-88458-0.

MANAHARAN, T., TENG, L.L., APPLETON, D., MING, C.H., MASILAMANI, T. and PALANISAMY, U.D., 2011. Antioxidant and antiglycemic potential of peltophorum pterocarpum plant parts. Food Chemistry, vol. 129, no. 4, pp. 1355-1361. http:// dx.doi.org/10.1016/j.foodchem.2011.05.041.

MATSUMOTO, K., WATANABE, Y., OHYA, A. and YOKOYAMA, S., 2006. Young persimmon fruits prevent the rise in plasma lipids in a diet-induced murine obesity model. Biological \& Pharmaceutical Bulletin, vol. 29, no. 12, pp. 25322535. http://dx.doi.org/10.1248/bpb.29.2532. PMid:17142997.

NOREEN, H., SEMMAR, N., FARMAN, M. and MCCULLAGH, J., 2017. Measurement of total phenolic content and antioxidant activity of aerial parts of medicinal plant Coronopus didymus. Asian Pacific Journal of Tropical Medicine, vol. 10, no. 8, pp. 792-801. http://dx.doi.org/10.1016/j.apjtm.2017.07.024. PMid:28942828.

OHKAWA, H., OHISHI, N. and YAGI, K., 1979. Assay for lipid peroxides in animal tissues by thiobarbituric acid reaction. Analytical Biochemistry, vol. 95, no. 2, pp. 351-358. http://dx.doi. org/10.1016/0003-2697(79)90738-3. PMid:36810.

PAL, D., BANERJEE, S. and GHOSH, A.K., 2012. Dietaryinduced cancer prevention: an expanding research arena of emerging diet related to healthcare system. Journal of Advanced 
Pharmaceutical Technology \& Research, vol. 3, no. 1, pp. 16-24. PMid:22470889.

PROLL, J., PETZKE, J., EZEAGU, E. and METGES, C., 1998. Low nutrition quality of unconventional tropical crop seeds in rats. The Journal of Nutrition, vol. 128, no. 11, pp. 2014-2022. http://dx.doi.org/10.1093/jn/128.11.2014. PMid:9808658.

REEVES, P.G., NIELSEN, F.H. and FAHEY JUNIOR, G.C., 1993. AIN-93 purified diets for laboratory rodents: final report of the American Institute of Nutrition ad hoc writing committee on the reformulation of the AIN-76A rodent diet. The Journal of Nutrition, vol. 123, no. 11, pp. 1939-1951. http://dx.doi. org/10.1093/jn/123.11.1939. PMid:8229312.

REITMAN, S. and FRANKEL, S., 1957. A colorimetric method for the determination of serum glutamic oxalacetic and glutamic pyruvic transaminases. American Journal of Clinical Pathology, vol. 28, no. 1, pp. 56-63. http://dx.doi.org/10.1093/ajcp/28.1.56. PMid:13458125.

RICHARD, D., KEFI, K., BARBE, U., BAUSERO, P. and VISIOLI, F., 2008. Poly unsaturated fatty acids as antioxidants. Pharmacological Research, vol. 57, no. 6, pp. 451-455. http:// dx.doi.org/10.1016/j.phrs.2008.05.002. PMid:18583147.

RICHMOND, W., 1973. Preparation and properties of a cholesterol oxidase from Nocardia sp. and its application to the enzymatic assay of total cholesterol in serum. Clinical Chemistry, vol. 19, no. 12, pp. 1350-1356. PMid:4757363.

SAMI, R., LI, Y., QI, B., WANG, S., ZHANG, Q., HAN, F., MA, Y., JING, J. and JIANG, L., 2014. HPLC Analysis of water-soluble vitamins (B2, B3, B6, B12, and C) and Fat-Soluble Vitamins (E, K, D, A, and $\beta$-Carotene) of Okra (Abelmoschus esculentus). Journal of Chemistry, vol. 1, pp. 1-6. http://dx.doi. org/10.1155/2014/831357.

SANCHETI, S., SANCHETI, S., BAFNA, M., LEE, S. and SEO, S., 2011. Persimmon leaf (Diospyros kaki), a potent alphaglucosidase inhibitor and antioxidant: alleviation of postprandial hyperglycemia in normal and diabetic rats. Journal of Medicinal Plants Research, vol. 5, no. 9, pp. 1652-1658.

SIDIK JUNIOR, S.M. and AHMAD, R., 2003. Dietary management of a patient with diabetes mellitus: a case report. Malaysian Journal of Nutrition, vol. 9, no. 2, pp. 137-144. PMid:22691734.
SINGH, S. and JOSHI, H., 2011. Diospyros kaki (Ebenaceae): a review. Asian Journal of Pharmaceutical Sciences, vol. 1, pp. 55-58.

SINHA, A.K., 1972. Colorimetric assay of catalase. Analytical Biochemistry, vol. 47, no. 2, pp. 389-394. http://dx.doi. org/10.1016/0003-2697(72)90132-7. PMid:4556490.

SUN, L., ZHANG, J., LU, X., ZHANG, L. and ZHANG, Y., 2011. Evaluation to the antioxidant activity of total flavonoids extract from persimmon (Diospyros kaki L.) leaves. Food and Chemical Toxicology, vol. 49, no. 10, pp. 2689-2696. http://dx.doi. org/10.1016/j.fct.2011.07.042. PMid:21802475.

TAYLOR, S.D. and HILL, B., 2004. Recent advances in protein tyrosine phosphatase $1 \mathrm{~B}$ inhibitors. Expert Opinion on Investigational Drugs, vol. 13, no. 3, pp. 199-214. http://dx.doi. org/10.1517/13543784.13.3.199. PMid:15013940.

TSURUNAGA, Y., TAKABAYASHI, Y., NISHI, M. and SUZUKI, Y., 2011. Differences in the ascorbic acid, astragalin, and polyphenol contents, and the DPPH radical scavenging activity of 22 commercial persimmon leaf tea products. Journal of Home Economics of Japan, vol. 62, pp. 437-444.

UEDA, K., KAWABATA, R., IRIE, T., NAKAI, Y., TOHYA, Y. and SAKAGUCHI, T., 2013. Inactivation of pathogenic viruses by plant-derived tannins: strong effects of extracts from persimmon (Diospyros kaki) on a broad range of viruses. PLoS One, vol. 8, no. 1, pp. 1-10. http://dx.doi.org/10.1371/journal. pone.0055343. PMid:23372851.

VEBERIC, R., JURHAR, J., MIKULIC-PETKOVSEK, M., STAMPAR, F. and SCHMITZER, V., 2010. Comparative study of primary and secondary metabolites in 11 cultivars of persimmon fruit (Diospyros kaki L.). Food Chemistry, vol. 119, no. 2, pp. 477-483. http://dx.doi.org/10.1016/j.foodchem.2009.06.044.

YANAR, M., BUYUKCAPAR, H.M., ERCEN, Z. and ERDOGAN, E., 2010. the evaluation of Heated Culban, Viciaperegrina as a partial replacement for fish meal in diets of Nile Tilapia, Oreochromisniloticus. Journal of Animal and Veterinary Advances, vol. 9, no. 6, pp. 1088-1093. http://dx.doi. org/10.3923/javaa.2010.1088.1093.

ZOLLNER, N. and KIRSCH, K., 1962. Colorimetric method for determination of total lipids. Journal of Experimental Medicine, vol. 135 , pp. $545-561$. 